\title{
THE SYSTEM OF PRONOMINAL ADDRESS IN LATVIAN: A SOCIOLINGUISTIC ASPECT
}

\author{
Linda Lauze
}

\begin{abstract}
This paper represents the study of sociolinguistic variation. The Latvian language has two singular personal pronouns $t u(\mathrm{~T})$ and $j \bar{u} s(\mathrm{~V})$ used for addressing one person but sociolinguistic processes in society reflects that the use of the $T$ pronoun intensifies outside informal speech situations. The aim of the research is to characterize the system of pronominal address as well as to test the steadiness of the $\mathrm{V}$ pronoun $(j \bar{u} s)$ in the Latvian language. The empiric part of the research is a qualitative study based on personal interviews, direct observation, and responses in two questionnaires distributed in 19992000 and in 2018.

The use of Latvian address forms has been changed in comparison with the Soviet period. For instance, in education. It seems that the high prestige of English and changes of communication style in Latvia are one of the factors making a positive linguistic attitude to the wider use of the T pronoun. However, according to the results of the research, at present Latvians are not ready to reject the pronoun jüs. This was concluded in both questionnaires by answers of $85.5 \%$ of respondents in 1999 2000 and $87 \%$ - in 2018. The Latvian personal pronoun $j \bar{u} s$ as a significant part of the address system is no doubt the feature of Latvia's culture.
\end{abstract}

UDC classification: 811.174 , DOI: https://doi.org/10.12955/pss.v1.60

Keywords: Latvian, pronominal adress, communication, English, 8127 sociolinguistics.

\section{Introduction}

The Latvian language has a very rich system of address including pronominal address. On the one hand, the first name and the personal pronoun $t u$ or $j \bar{u} s$ are used for an address. On the other hand, the form made of the surname in genitive case and title kungs 'mister' or kundze 'madam' following it exists as an address form in society.

The speaker must choose one from two singular personal pronouns of the Latvian language, $t u(\mathrm{~T})$ being familiar and informal, whereas $j \bar{u} s(\mathrm{~V})$ - polite and more formal. The juxtaposition of two pronouns of the $2^{\text {nd }}$ person used for an address exist also in other European languages, for instance, French vous $t u$, German Sie - du, Italian $l e i-t u$, Russian $v y-t y$, Spanish $u s t e d-t u$, Lithuanian $j \bar{u} s-t u-t a m s t a$, though not in English. As John Lyons states, "Social psychologists have investigated the use of T and $\mathrm{V}$ in terms of the concepts of power and solidarity, on the one hand, and of reciprocal and nonreciprocal, on the other. Generally speaking, we can say that non-reciprocal usage indicates an acknowledged difference of status" (Lyons, 1981, p. 318).

In 2018 the following issue was proposed in the conference "Baltic Languages and Culture" at Klaipeda University (Lithuania) - what would you like to save in Baltic languages for future generations? It has suggested to return to the author's research on the system of Latvian address after about twenty years and to test the significance of the pronoun $\mathrm{V}$. The formal pronoun has disappeared in some languages, for instance, in English, Swedish. English thou was gradually lost in everyday speech in the 17th century and is sometimes used in poetry (Barber, 2004, p. 187).

The aim of the research is to characterize the system of pronominal address as well as to test the steadiness of the $\mathrm{V}$ pronoun $(j \bar{u} s)$ in the Latvian language taking into consideration a sociolinguistic aspect. As Latvia regained its status as an independent state, since the 1990s the sociolinguistic situation has changed dramatically in Latvia in comparison with the Soviet period. Speaking about lexical changes in Latvian colloquial speech, it is emphasized that the democratization of social processes left an impression of a rather great freedom of expression in the 1990s (Ernstsone, 1996). Democratic tendencies, orientation towards the West as well as the influence of American sociolinguistic behavior all these factors are reflected in the use of Latvian address. Sociolinguists are aware that colloquial speech as an informal and familiar variety of the language tends to the usage of the T pronoun. The impact of colloquial speech rules is intensified in mass media, advertisements, education (see Blūmane, 2009).

\section{Review of the Literature}

The theoretical basis is findings of the theory of address forms which are reflected in works of Latvian and foreign linguists and other researchers (see Brown and Gilman, 1982; Brown and Levinson, 1987;

\footnotetext{
${ }^{1}$ Kurzeme Institute of Humanities, Liepāja University, Latvia, linda.lauze@liepu.lv
} 
Trudgill, 2000; Spolsky, 2003; Kretzenbacher et al., 2006). The analysis of the pronominal address is set up using the theory of the pronouns of solidarity and power according to Brown and Gilman. The system of pronominal address is to be considered in close connection not only with the linguistic but also the social context as well. It is necessary to stress that the social context includes also the aspect of politeness (see Brown and Levinson, 1987; Spolsky, 2003; Lauze, 2019).

In Latvia, several linguists have studied the use of address forms. Jānis Sīlis has described the issues of translation from a contrastive point of view (Sîlis, 1980; Sîlis, 2009). He has studied the use of address forms in the Soviet period when the address form biedri 'comrade' was used (Sîlis, 1988). Nowadays the address form biedri/biedre is not used any more. The author of this paper has analyzed age and gender differences in the usage of address including pronominal address (Lauze, 2001; 2002). Anda Blūmane has highlighted changes in schools in Latvia. Her research is based on direct observations of everyday communication among students, teachers and the school administration (Blūmane, 2009).

\section{Methodology}

The empiric part of the research is a qualitative sociolinguistic study based on personal interviews, direct observations during social events in which the author was a participant, and responses in questionnaires that stated the use of address forms involving pronominal address in Latvian.

200 respondents took part in the first questionnaire. To compare these results of the survey data carried out in 1999-2000 the same methodology with the same number of respondents and the same sample was used in the second questionnaire distributed in 2018. The data involved age stratification beginning with the age of 15 till 65 and more with representatives in five groups covering all generations. There were 20 women and 20 men in each age group. All respondents are Latvians. Attention was also focused on differences among gender and age groups.

\section{Results}

When characterising the system of pronominal address it is necessary to point out that there exist two singular personal pronouns in Latvian. As it is mentioned above, the $\mathrm{V}$ pronoun is polite and more formal, expressing respect when both communication partners do not have an equal social status or gender and age differences are important. The $\mathrm{V}$ pronoun reflects also distant relationship especially in official speech situations. Societal norms and speech etiquette set that a stranger is addressed by the V pronoun. The $\mathrm{T}$ pronoun is used by persons who are acquainted, who have close relationship and who do not have a great difference of age or social status. The $\mathrm{T}$ pronoun dominates when family members, other children up to age 16, close friends, classmates, persons practicing the same hobby, etc. are being addressed. In certain speech situations the $\mathrm{T}$ pronoun contains semantics of contempt and anger (see also Brown and Gilman, 1982).

When analysing the answers to the question Do you mind if a stranger addresses you by tu without a previous agreement?, the results show a rather democratic linguistic attitude. Almost half of the respondents only sometimes do not accept possibility if a stranger addresses him/her by the $\mathrm{T}$ pronoun without a previous agreement (see Table 1). According to societal norms and traditions of the Latvian culture the $\mathrm{V}$ pronoun have to be used in the conversation with a stranger.

\begin{tabular}{|c|c|c|}
\hline \multicolumn{3}{|c|}{ Table 1: Linguistic attitude to the use of the T pronoun without a previous agreement } \\
\hline \multicolumn{3}{|c|}{ Answers \% } \\
\hline Negative & 42 & 28.5 \\
\hline Sometimes negative & 41.5 & 45 \\
\hline Positive & 16.5 & 26.5 \\
\hline Source & Author $1999-2000$ & Author 2018 \\
\hline
\end{tabular}

Although $16.5 \%$ of positive answers given by respondents in 1999-2000 have risen to $26.5 \%$ in 2018 strengthening the new function of the $\mathrm{T}$ pronoun, in communication with a stranger the $\mathrm{V}$ pronoun is more appropriate (see also Lauze, 2019).

The use of Latvian address forms has been changed in comparison with the Soviet period. For instance, in education. At school, the address skolotäj 'teacher' is the same but the forms for addressing him/her differ. This title and the last name following it was used in the Soviet period, however, nowadays the form skolotāj/skolotāja with the first name following it dominates. In Latvian it is possible to use the 
first name with the $\mathrm{T}$ pronoun and also the first name with the $\mathrm{V}$ pronoun as a semi-official form of address.

Let us illustrate this change by the following part of the dialogue between the author attending a primary school in the Soviet period and her first primary school teacher, an about 65 years old lady.

The author said, “Teacher, I don't know your name."

The teacher asked, "Have you forgotten it?

The author answered, "No, I have not. I know only your surname. Now when I started receiving messages from my son's teacher signed a teacher Rita I suddenly realized that I don't know your first name."

The teacher exclaimed, "Oh! I am Velta."

At present taking into consideration the multicultural context the tendency to use the $T$ pronoun wider has arisen doubts about the steadiness of the Latvian V pronoun. Do Latvians need the V pronoun?

A 23 years old female student says: "It is like a fence. A fence between us that separate us but it is also like a sheltering wall that protects me from you and you from me."

Answering to the question Would it be necessary to reject pronoun jüs addressing one person in the Latvian language? the negative answer dominates (see Table 2).

\begin{tabular}{|c|c|c|}
\hline \multicolumn{3}{|c|}{ Table 2: Steadiness of the pronoun $j \bar{u} s$} \\
\hline \multicolumn{3}{|c|}{ Answers \% } \\
\hline Negative & 85.5 & 87 \\
\hline Positive & 3 & 2 \\
\hline Don't know & 11.5 & 22 \\
\hline Source & Author 1999-2000 & Author 2018 \\
\hline
\end{tabular}

There is no big difference in the results of both questionnaires. It is necessary to emphasize that the percentage of the answer don't know is higher now. About 20 years ago all representatives of the older group (65 and more years old respondents) gave an answer no being sure that they need the formal pronoun $j \bar{u} s$. There is no age or gender group reflecting the same result - a strict no as $100 \%$ of all answers.

To test a traditional linguistic attitude versus a modern one, not only the knowledge of language is important but also the use of language in communication. Similar to German, "in spite of the two competing systems, there are still clear cut rules that lead to the generally accepted use of $\mathrm{T}$ and $\mathrm{V}$ in many standard situations" (Kretzenbacher et al., 2006, p. 17.2.). The steadiness of traditional rules of societal norms and politeness show answers to the question In case a journalist addresses a person he/she is interviewing in everyday communication by the pronoun tu which pronoun should be used in the interview? $81.82 \%$ of respondents prefer the use of the $\mathrm{V}$ pronoun in this public speech situation and only $18.8 \%$ choose the T pronoun according the results of the questionnaire distributed in 2018.

\section{Discussion}

This ability of Americans to build contact, a social bridge with an interlocutor in a very short time, say, the first five minutes of conversation is reflected in the use of first name and the $T$ prounoun for an address in the Latvian language. In many cases it is evaluated positively in Latvia too. When analysing the use of the pronominal address, Blūmane considers an innovation in the Latvian language that is "the expansion of the use of the pronoun $t u$ in situations where the respectful and reverential address form $J \bar{u} s$ was used a few decades ago" (Blūmane, 2009, 206).

Paradoxically, the following stereotype is widespread that foreign languages without the special formal pronoun do not have such difficulties in communication, for instance, awkwardness, as in Latvian. In this context Latvian and English are often compared. Let us illustrate this point of view by the quotation from an interview:

- In the English language everything is simple. They have only one personal pronoun to use in addressing somebody. And that is you which means both tu and jūs simultaneously (female student, 19 years old). 
It causes translation difficulties "related not only to sociocultural and sociopragmatic differences in semantics of pronominal address forms, but also to differences of similar character in situational contexts of source and target languages" (Sīlis, 2009, 235).

It is necessary to point out that the Latvian language as a flexive language shows the choice of pronoun in a sentence by using a singular or plural verb form of the $2^{\text {nd }}$ person even in case the pronoun is missed because Latvian grammar allows such ellipsis. In everyday communication the following phenomena is sometimes observed that in speech situation when one of the speakers is not sure of his/her social relationships as close, semi-official or distant and therefore also by choosing the appropriate pronoun between $\mathrm{T}$ and $\mathrm{V}$, he/she uses the pronoun of the $3^{\text {rd }}$ person in an implicated form of address.

It does not mean that the juxtaposition of formal and informal varieties does not exist in English. "The addressee will affect the forms of language used by the speaker/writer (e.g. a speaker is likely to speak differently to close friends and to a boss at work)." (A Dictionary of Sociolinguistics, 2004, p. 5) Although English has lost the thou/you distinction, it still offers a range of address forms Title Alone, Title + Surname to First Name to Multiple Names (Spolsky, 2003, p. 21). At the same time the level of solidarity in communities speaking English and Scandinavian languages is very high and it is reflected in the use of address forms.

English is of enormous importance, leaving a noticeable and less noticeable impact on other European languages. The apparent acceptance of English makes it not only a globalized language but also a medium and channel of globalization (Veisbergs, 2012, p. 104). Maija Brēde in her study of English borrowings in Latvian has shown that about 10 years ago assimilated English words were used with Latvian endings and spelling according to their pronunciation in adapted form (Brēde, 2016). At present on the Internet and in other texts it is observed that English words are used in the original. This looks like a dangerous tendency for the Latvian language and shows that the influence of English has become aggressive.

\section{Conclusions}

The collective ethnolinguistic vitality of Latvian can be evaluated as high, taking into consideration demographic factors, institutional support, and its status of the state language (Druviete, 2017, p. 32). However, we live under the impact of global English. It seems that the high prestige of English and changes of communication style in Latvia are one of the factors making a positive linguistic attitude to the wider use of the T pronoun. Communication is not isolated from the surrounding world; it exists in a multicultural context. Studies of spoken communication point out that the influence of the rules of colloquial speech are intensified outside the informal field of activity.

According to the results of the research, it seems that at present Latvians are not ready to reject the pronoun $j \bar{u} s$. It was concluded in both questionnaires by answers of $85.5 \%$ of respondents in 19992000 and $87 \%$-in 2018. There is a small change in the use of Latvian pronouns $t u$ and $j \bar{u} s$, nevertheless, the role of the pronoun $t u$ is increasing. The first name and the $\mathrm{T}$ pronoun following it is a typical informal address form but the first name and the $\mathrm{V}$ pronoun are used as sociolinguistic variation for semi-official address reflecting the specific significance of the $\mathrm{V}$ pronoun in an untypical model. The Latvian personal pronoun $j \bar{u} s$ as a significant part of the address system is no doubt a feature of Latvia's culture.

\section{References}

Barber, C. (2004). The English Language: A Historical Introduction. Fifth printing. Cambridge: Cambridge University Press.

Blūmane, A. (2009). Sociolinguistic Analysis of Address Usage in General Educational Institutions in Latvia. Kalbos Kultūra. T. 82. Vilnius: Lietuvių kalbos institutas, pp. 202-213.

Brēde, M. (2016). Changeability within the Lexical Level of Latvian under the Impact of Global English. Scriptus Manet. Nr. 3. Liepāja: LiePA, pp. 62-77.

Brown, P. and Levinson, S. (1987). Politeness: Some Universals in Language Usage. Cambridge: Cambridge University Press.

Brown, R. and Gilman, A. (1982). The Pronouns of Power and Solidarity. Language and Social Context. Ed. By Pier Paolo Giglioli. Penguin Books, pp. 252-282.

A Dictionary of Sociolinguistics. (2004). Ed. By Joan Swann, Ana Deumert, Theresa Lillis, and Rajend Mesthrie. Tuscaloosa: The University of Alabama Press. 
Druviete, I. (2017). Latvian in the Context of Global Sociolinguistic Processes. The Language Situation in Latvia: 2010 2015. A Sociolinguistic Study. (Valodas situācija Latvijāa: 2010-2015. Sociolingvistisks pētījums.) Scientific Editor L.Lauze, Editor-in-Chief G. Kḷava. Rīga: LVA, pp. 11-33.

Ernstsone, V. (2006). Latviešu sarunvaloda Austrumu un Rietumu ietekmju krustpunktā. [The Conversational Latvian in the Point of Intersection of the Influences of East and West.] Lietuviešu un latviešu sastatāmās stilistikas jautājumi. Šiauliai: Všl Šiaulių universiteto leidykla, pp. 192.-203. [In Latvian]

Kretzenbacher, H., Clyne, M., and Schüpbach, D. (2006). Pronominal Address in German: Rules, Anarchy and Embarrassment Potential. Australian Review of Applied Linguistics 29 (2): pp. 17.1-17.18. DOI: 10.2104/aral0617.

Lauze, L. (2001). Dzimuma atšķirības uzrunas lietojumā. [Gender Differences in the Usage of Address.] Vārds un tā pētī̌sanas aspekti. Rakstu krājums 5. Liepāja: LiePA, pp. 286-295. [In Latvian]

Lauze, L. (2002). Vecuma atškirirības uzrunas lietojumā. [Age Differences in the Usage of Address.] Vārds un tā pētī̌sanas aspekti. Rakstu krājums 6. Liepāja: LiePA, pp. 434-440. [In Latvian]

Lauze, L. (2019). Lingvistiskā attieksme pret svešinieku uzrunas lietojumā. [Linguistic Attitude Towards a Stranger in the Use of Address.] VALODA - 2019. Valoda dažādu kultūru kontekstā. XXIX Zinātnisko rakstu krājums. Atb. red. S. Polkovņikova. Daugavpils: Daugavpils Universitātes Akadēmiskais apgāds „Saule”, pp. 162.-167. [In Latvian]

Lyons, J. (1981). Language and Linguistics: an Introduction. Cambridge; New Yourk: Cambridge University Press. Sîlis, J. (1988). Uzrunas "biedri/biedre(ne)" lietošanas problēmas. [Problems of the Usage of Address Forms "biedri/biedre(ne)" ('Comrade').] Valodas aktualitātes - 1987. Rīga: Zinātne, pp. 206-216. [In Latvian]

Sīlis, J. (2009). Tulkojumzinātnes jautājumi. Teorija un prakse. [Issues of Translation Studies. Theory and Practice.] Ventspils: Ventspils Augstskola. [In Latvian]

Spolsky, B. (2003). Sociolinguistics. Fourth impression. Oxford: Oxford University Press.

Trudgill, P. (2000). Sociolinguistic: an Introduction to Language and Society. Fourth edition. London: Penguin Books.

Veisbergs, A. (2012). Semantic Change in Latvian under the Influence of English. Baltic Journal of English Language, Literature and Culture. Volume 2. Riga: University of Latvia, pp. 103-121.

Sīlis, J. (1980). Семиотика форм английского и латымского обращения. [Semiotics of Forms of English and Latvian Address.] Candidate of Philological Sciences dissertation, Mikhail Lomonosov Moscow State University. [In Russian] 